\title{
Betalains from prickly-pear fruit: An alternative natural coloring for food
}

\section{Betalaínas de tuna: Un colorante natural alternativo para alimentos}

\author{
RAMÍREZ-GRANADOS, Juan Carlos $\dagger^{*}$, GÓMEZ-LUNA, Blanca Estela, MORALES-VARGAS, \\ Adán Topiltzin and MEJÍA-TENIENTE, Laura
} Universidad de Guanajuato, División de Ciencias de la Salud e Ingenierías, Departamento de Ingeniería Agroindustrial.
Prolongación Río Lerma s/n. Col. Suiza, Celaya, Gto., México. C.P. 38060

ID $1^{\text {er }}$ Autor: Juan Carlos, Ramírez-Granados / ORC ID: 0000-0001-6460-6472, Researcher ID Thomson: S-5874-2018, CVU CONACYT ID: 167866

ID $1{ }^{\mathrm{er}}$ Coautor: Blanca Estela, Gómez-Luna / ORC ID: 0000-0001-6345-0461, CVU CONACYT ID: 101592

ID $2^{\text {do }}$ Coautor: Adán Topiltzin, Morales-Vargas / ORC ID: 0000-0003-0490-5934, CVU CONACYT ID: 176575

ID $3^{\text {er }}$ Coautor: Laura, Mejía-Teniente / ORC ID: 0000-0002-1302-8139, SCOPUS ID: 36773615700, CVU CONACYT ID: 217338

\begin{abstract}
Food coloring are additives that are usually incorporated into foods to make them more attractive to people. However, some mineral and synthetic dyes used in the food industry are related to harmful effects on human health. Natural dyes, such as betalains extracted from prickly-pear fruit, have fewer restrictions on use and represent a healthier alternative to enhance the appearance of food. In this work, a process to extract betalains from the pulp and peel of Cardona pricklypear fruit was implemented and optimized. The extracted pigment was encapsulated in cornstarch. Then, it was analyzed the effect of the extract/encapsulant ratio on the amount of encapsulated betalains. It was found that the peel of this variety of prickly-pear fruit represents about $48 \%$ of its total weight. It was also demonstrated that concentrations of betalains in the peel $(12.0 \mathrm{mg} / \mathrm{g})$ and in the pulp $(16.5$ $\mathrm{mg} / \mathrm{g}$ ) are alike. For these reasons, we consider that the peel of red prickly-pear fruit is an ideal material for the extraction of betalains because it is a waste material with high content of red pigments.
\end{abstract}

Food coloring, Betalains, Prickly-pear fruit

\begin{abstract}
Resumen
Los colorantes alimenticios son aditivos que usualmente son incorporados a los alimentos para que sean más atractivos para las personas. Sin embargo, algunos colorantes minerales y sintéticos usados en la industria alimenticia están asociados a efectos nocivos para la salud. Los colorantes naturales, tales como las betalaínas de las tunas, tienen menos restricciones de uso y representan una alternativa más saludable para mejorar la apariencia de los alimentos. En este trabajo se implementó y optimizó un proceso de extracción de betalaínas provenientes de la pulpa y cáscara de tunas Cardona. El colorante extraído fue encapsulado en fécula de maíz. Luego, se analizó el efecto de la relación extracto/encapsulante en la cantidad de betalaínas encapsuladas. Se encontró que la cáscara de esta variedad de tuna representa cerca del $48 \%$ de su peso total y que la concentración de betalaínas en la cáscara $(12.0 \mathrm{mg} / \mathrm{g})$ es similar a la de la pulpa $(16.5 \mathrm{mg} / \mathrm{g})$. Por estas razones, consideramos que la cáscara de tuna roja es un material idóneo para la extracción de betalaínas, ya que es un material de desecho con alto contenido de pigmentos rojos.
\end{abstract}

Colorante alimenticio, Betalaínas, Tuna

Citation: RAMÍREZ-GRANADOS, Juan Carlos, GÓMEZ-LUNA, Blanca Estela, MORALES-VARGAS, Adán Topiltzin and MEJÍA-TENIENTE, Laura. Betalains from prickly-pear fruit: An alternative natural coloring for food. Journal-Agrarian and Natural Resource Economics. 2019 3-5: 1-10

\footnotetext{
* Correspondence to Author (email: jcramirez@ugto.mx)

$\dagger$ Researcher contributing as first author.
} 


\section{Introduction}

Consumers express a strong preference for products with attractive appearance, since color is the first attribute that is judged in food. This is decisive since in innumerable tests it has been proven that when the color of a food changes without altering its shape, aroma or other attributes, a rejection response is obtained from consumers. Food, both in its natural and processed form, has a characteristic and welldefined color by which consumers identify them. Color is often used to determine the pigment content of a food, which in turn is a quality index (González and Vicente, 2007).

It can also provide some information about the edible quality of a food, about its identity or about the intensity of the flavor. Therefore, in many cases the decisive role of color on the person's experience in tasting a food has been proven (Badui, 2006). Color is an organoleptic quality of food and is appreciated through the sense of sight. It is also usually considered a psychological factor of appreciation and a criterion for choosing a food product; even in products of plant origin it is related to the possibility of evaluating the degree of maturation.

In this work, color is approached as a quantifiable variable in determining the quality of food quickly, accurately and objectively. Today there are different tools to measure color reliably and are increasingly accurate and easy to interpret. The use of these tools in the food industry is increasing, especially with new digital vision technologies, which are noninvasive techniques for food and allow inspection of an entire production, while ensuring the safety and quality of the food. In addition, the image can be correlated with other properties of food, such as texture, size and distribution of ingredients.

\section{Justification}

The addition of chemicals to food today is a daily occurrence. These substances help in food processing by improving or highlighting a special feature; These substances are called additives. These come from various natural and artificial origins, according to Codex Alimentaius (CODEX, 1995).
The concept of additive refers to any substance that, regardless of its nutritional value, is intentionally added to a food in controlled quantities and for technological purposes.

One of the main additives in foods are dyes that reinforce or vary the color. Processed foods usually have artificial coloration in order to make them more attractive to consumers. Currently these are obtained through three routes that are: mineral, synthetic and natural, currently being the most used synthetic. However, artificial colors are being replaced by natural ones because several studies have shown that these can cause harmful effects in the body. For example, tartrazine causes hives in less than $0.01 \%$ of the population exposed to it: while erythrosine is related to thyroid tumors in rats.

For these reasons and the current change in consumer trends, natural dyes are an excellent alternative to enhance the color of food. These are usually obtained from non-food biological materials such as plants or insects or are formed spontaneously by heating a food such as in the case of caramel. Natural dyes are generally considered harmless and the specific limitations in their use are less than those that affect synthetic dyes.

\section{Definition of the problem}

People associate the color of food with its quality. Processed foods are usually added with artificial colors to reinforce or modify their color with the intention that consumers accept them for their good looks. However, the correlation between color and quality is not always valid. The abuse of dyes can hide defects or deficiencies of the food, harming the consumer. Moreover, some artificial colors have harmful effects on health, especially when consumed in amounts greater than the recommended daily intake. To avoid these inconveniences, some artificial dyes are being replaced by natural dyes.

\section{Hypothesis}

The prickly peel of the Cardona variety is a plant material with a high content of reddish natural pigments that could be used in the food industry to highlight the color of food, giving added value to this material that is commonly discarded by people. 


\section{Goals}

The general objective and specific objectives of this work are presented below.

\section{Overall objective}

Obtain a natural dye for the food industry from the fruit of the cacti genus of Opuntia spp.

\section{Specific objectives}

- Extract the natural pigments from the fruit and determine its concentration through ultraviolet and visible spectrophotometry.

- Propose possible applications of extracted pigments.

\section{Theoretical framework}

\section{Betalain content}

The quantification of the pigments was carried out by spectrophotometric methods based on the photometric properties of these compounds, according to which they absorb light in certain regions of the visible spectrum (betaxanthines: 470-480 $\mathrm{nm}$ and betacyanines: $538-540 \mathrm{~nm}$ ).

The absorbance that is determined in the extract solutions at the indicated wavelengths must be less than 1 . The betalaine content is calculated using the following equation proposed by Castellanos-Santiago and Yahia in 2008, through the absorbance of the extracts of betalains at 538 and $483 \mathrm{~nm}$. For the conversion of absorbance units to concentration units the expression was used:

$$
\mathrm{B}[\mathrm{mg} / \mathrm{g}]=(\mathrm{A} \times \mathrm{FD} \times \mathrm{PM} \times \mathrm{V}) /(\varepsilon \times \mathrm{P} \times \mathrm{L}),
$$

where $\mathrm{B}$ represents betacyanins or betaxanthines, $A$ is the absorbance at $538 \mathrm{~nm}$ for betacyanins and $483 \mathrm{~nm}$ for betaxanthines, FD is the dilution factor at the time of reading on the spectrophotometer, PM is the molecular weight $($ Betanin $=550 \mathrm{~g} / \mathrm{mol}$ and Indicaxanthin $=308$ $\mathrm{g} / \mathrm{mol}), \mathrm{V}$ is the volume of the extract, $\varepsilon$ is the molar extinction coefficient $($ Betanin $=60000 \mathrm{~L}$ $/$ mol-cm, and Indicaxanthin $=48000 \mathrm{~L} / \mathrm{mol}-$ $\mathrm{cm})$ and $\mathrm{L}$ is the width of the cell $(1 \mathrm{~cm})$.

\section{Extraction of betalains by chemical maceration}

It is a widely used method for the extraction of natural pigments. This being a basic operation whose purpose is the separation of one or more components contained in a solid phase through the use of a liquid phase or solvent. The component is transferred to the liquid phase that receives the name of solute and is the one that is recovered, while the rest of insoluble material or plant material is discarded.

This type of operation can be carried out in one or multiple stages, being one stage in which the two phases are contacted for a while until equilibrium is reached, once reached the mechanical separation of the phases is achieved. The separation can be single or there can be multiple stages, and in turn it can be continuous or discontinuous.

For the extraction of these pigments, the fruit is macerated in water or the material is ground. In most cases, 20 to $50 \% \mathrm{v} / \mathrm{v}$ aqueous or methanol solutions in different percentages are used as solvents to achieve complete extraction (Piatelli, 1981).

\section{Pigment encapsulation}

Encapsulation can be defined as a technique whereby liquid drops, solid or gaseous particles, are covered with a porous polymeric film containing an active substance. This membrane, barrier or film is generally made of chain components to create a network with hydrophobic and / or hydrophilic properties (Fuchs et al., 2006). The term microencapsulation is similarly used in the food industry when low molecular weight substances are encapsulated or in small quantities, although the two terms, encapsulation and microencapsulation, are used differently (Yañez et al., 2002).

Among the first practical applications of microencapsulation, the pharmaceutical, medical, textile, food industry (Dutta et al., 2009), pesticide, cosmetics, chemistry (Fuchs et al., 2006), antimicrobial agents (Zong et al., 2009) biomedical and plastics (Dutta et al., 2009). 
Regarding the food area, the applications of this technique have been increasing due to the protection of encapsulated materials from factors such as heat and humidity, allowing to maintain its stability and viability. The microcapsules help the food materials used to resist the conditions of processing and packaging improving taste, aroma, stability, nutritional value and appearance of the products (Yañez et al., 2002; Montes et al. 2007).

The microencapsulation technique has allowed to solve some problems that limit the applications of ingredients and food additives, since it can control the elimination of flavorings; as well as reducing volatility, hygroscopicity and reactivity by increasing the stability of products under adverse environmental conditions.

\section{Encapsulation methods}

Some of the techniques used for microencapsulation are: spray drying, lyophilization, extrusion, fluidized bed coating, liposome entrapment, coacervation (Gibbs et al., 1999; Santinho et al., 2002), inclusion, centrifugal extrusion, rotational suspension, interfacial separation and polymerization (Wang et al., 2004), among others. The selection of the encapsulation method is based on costs, on the properties of the material to be encapsulated, on the desired size of the microparticles, on the application and on the release mechanism (Pedroza, 2002).

Spray drying is the most widely used encapsulation method in the food industry to encapsulate active compounds and protect materials economically, simply and continuously. Through this technique the solution or dispersion is atomized (with a nozzle or rotating disk) in the form of fine drops in a flow of hot air. When the small drops of liquid come into contact with the hot air a powder is instantly obtained due to the rapid evaporation of the water.

A wide variety of encapsulating materials for food applications have been studied; However, it is important to consider characteristics such as water solubility, permeability, ease of application, low viscosity in concentrated solutions and their hydrophobic or hydrophilic nature. All these factors will influence the characteristics of the final product (Gibbs et al., 1999).

\section{Encapsulating materials}

The main encapsulants used for this method are: carbohydrates (starch and derivatives, maltodextrins, corn syrups, cyclodextrins, carboxymethyl cellulose and derivatives), gums (arabic, mesquite, sodium alginate); lipids (waxes, paraffins, fats) and proteins (gelatin, soy protein, caseinates, whey, zein).

These encapsulants must have the ability to provide a stable emulsion during the spray drying process and have very good film-forming properties to provide a layer that protects the active ingredient from oxidation. The physical properties of the microcapsules depend on the temperature of the hot air, the degree of uniformity of the spray and the solids content in the emulsion.

\section{Methods and materials}

\section{Raw material}

The prickly pears of the Cardona variety or red prickly pears were obtained from the fruit vendor market in Celaya, Gto., Figure 1.

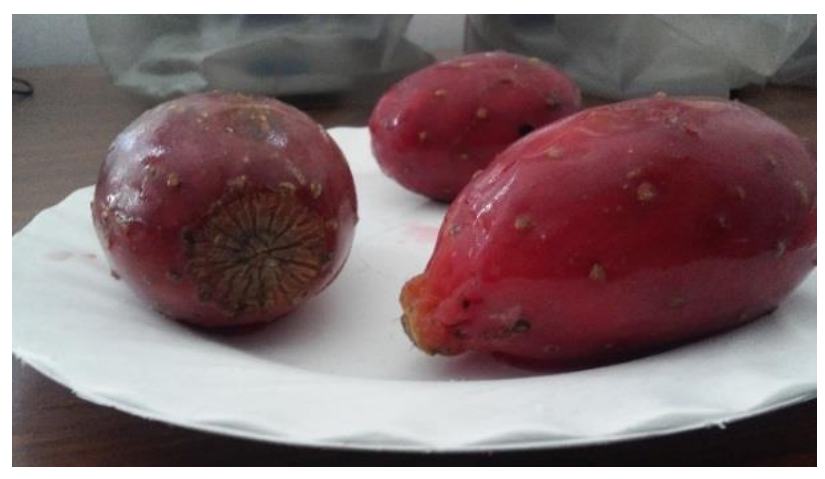

Figure 1 Tunas of the Cardona variety

\section{Selection and cleaning of the fruit}

The prickly pears were selected having the following considerations: intense color, ripe fruits, healthy and free of damage. This stage is of importance since fruits that are in a state of decomposition can affect the process of obtaining the dye (betalains). For disinfection it was washed with soap and water to remove spines and dirt. 


\section{Conditioning of the raw material}

The peel and pulp of the prickly pears were separated manually using good-edged stainless steel knives (Figure 2). Care was taken not to leave pulp attached to the shell. Considering that the dye that has the prickly pear peel degrades easily in the presence of high temperatures and in contact with sunlight, it is stored under refrigeration for later use.

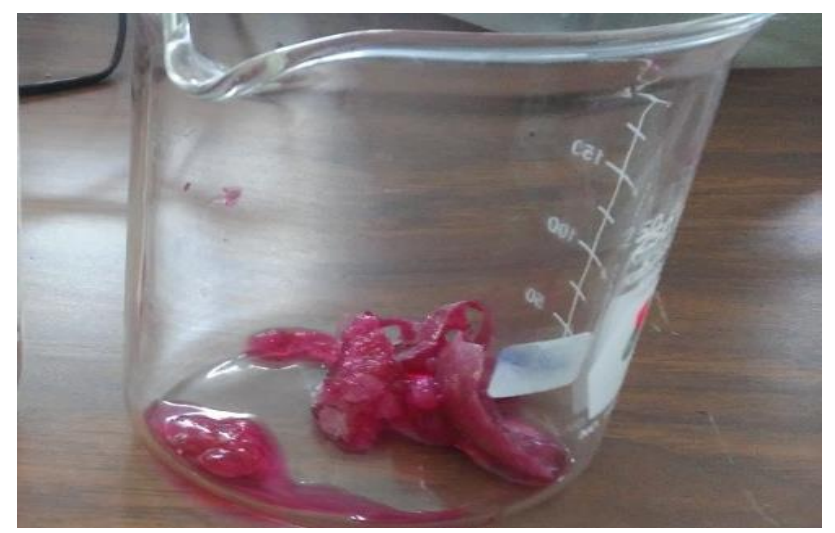

Figure 2 Prickly pears

\subsection{Obtaining the dye}

The extraction of betalaine-type pigments was carried out by means of chemical maceration, placing $270 \mathrm{~g}$ of fruit peel and separately another $270 \mathrm{~g}$ of pulp that were submerged in distilled water, (Figure 3). 3 extractions of 2 hours were performed until the fruit was discolored. After the procedure, a liter of extract was collected, then a filtration was carried out to eliminate the residue of particles that could interfere with the subsequent procedures.

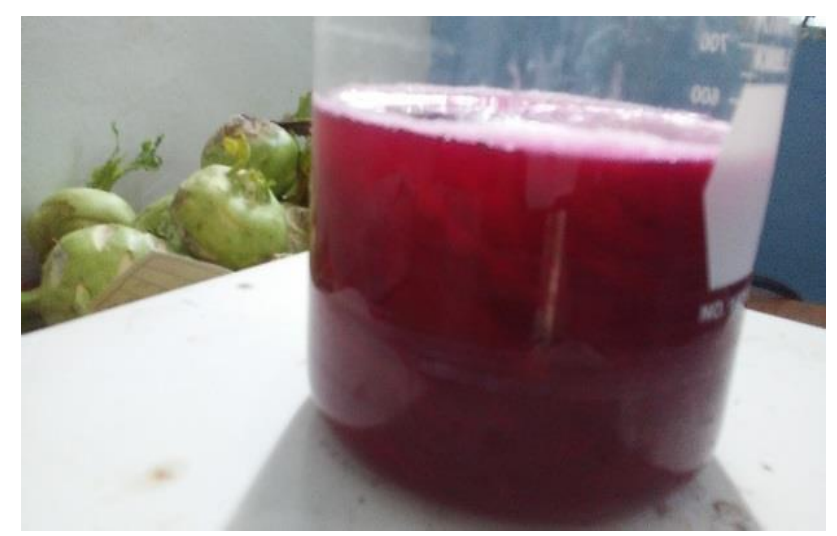

Figure 3 Red prickly pear coloring extract

The betalaine content of the crude extract was determined by a spectrophotometric method (Castellanos et al. 2008). The aqueous extract was dissolved to ensure that the absorbance (A) was in the optimal range $(0.8<\mathrm{A}<1.0)$, Figure 4.

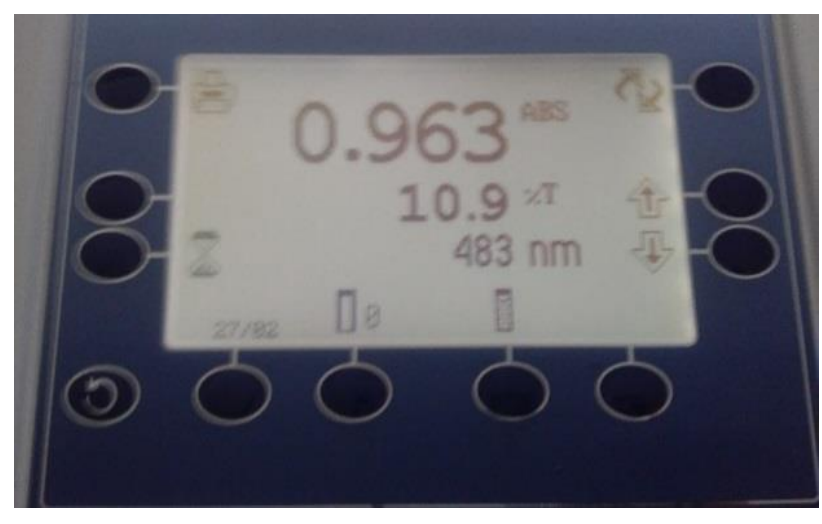

Figure 4 Typical absorbance of dilutions with red prickly pear pigment extract

\section{Results}

\section{Description of the fruit}

According to the analysis developed in the study, a description of the plant material used was made, Table 1.

\begin{tabular}{|l|l|}
\hline Characteristics & \multicolumn{1}{|c|}{ Description } \\
\hline Color & $\begin{array}{l}\text { Ripe fruit that has an intense reddish } \\
\text { peel, like its pulp. Free from damage } \\
\text { or stains. }\end{array}$ \\
\hline Form & $\begin{array}{l}\text { Ellipsoid } 4.0 \mathrm{~cm} \text { long and } 2.5 \mathrm{~cm} \\
\text { wide approx. }\end{array}$ \\
\hline Texture & Firm crust and soft pulp \\
\hline $\mathrm{pH}$ & 5.34 (shell). \\
\hline
\end{tabular}

Table 1 Physical and chemical description of red prickly pears

\section{Weight of prickly pear Cardona}

With an analytical balance, the weight of whole fruits and their peels was measured (Table 2). An average of $47.61 \%$ of the shell weight was determined in relation to the total weight of the prickly pears. Huaman-Congora studied in 2014 the prickly pears from the Department of Ayacucho in Peru and reported an average of $48.7 \%$.

\begin{tabular}{|l|r|r|r|}
\hline Sample & \multicolumn{1}{|c}{$\begin{array}{c}\text { Total } \\
\text { Weight } \\
(\mathbf{g})\end{array}$} & $\begin{array}{c}\text { Shell } \\
\text { Weight } \\
(\mathbf{g})\end{array}$ & $\begin{array}{c}\text { Shell weight } \\
\text { percentage (\%) }\end{array}$ \\
\hline 1 & 121 & 56.0 & 46.28 \\
\hline 2 & 120 & 61.0 & 50.83 \\
\hline 3 & 118 & 52.8 & 44.75 \\
\hline 4 & 130 & 70.0 & 53.85 \\
\hline 5 & 127 & 62.0 & 48.82 \\
\hline 6 & 132 & 54.3 & 41.14 \\
\hline Average & $\mathbf{1 2 5}$ & $\mathbf{5 9 . 4}$ & $\mathbf{4 7 . 6 1}$ \\
\hline
\end{tabular}

Table 2 Percentage of shell weight in relation to the total weight of Cardona prickly pears 
Almost $50 \%$ of the prickly pear is shell and is commonly discarded, which is why it constitutes an excellent organic material that can be used as a raw material to obtain natural dyes.

\section{Obtaining the crude extract}

In the Methods section the manner in which the extract was obtained was described in detail. The extract was obtained from fresh prickly pears that were washed, cut and separated in shell and pulp until $270 \mathrm{~g}$ of each of the latter were obtained. The solvent (distilled water) was used in several washes to obtain a liter of solute that was filtered to avoid interference with the plant material, Figure 5.

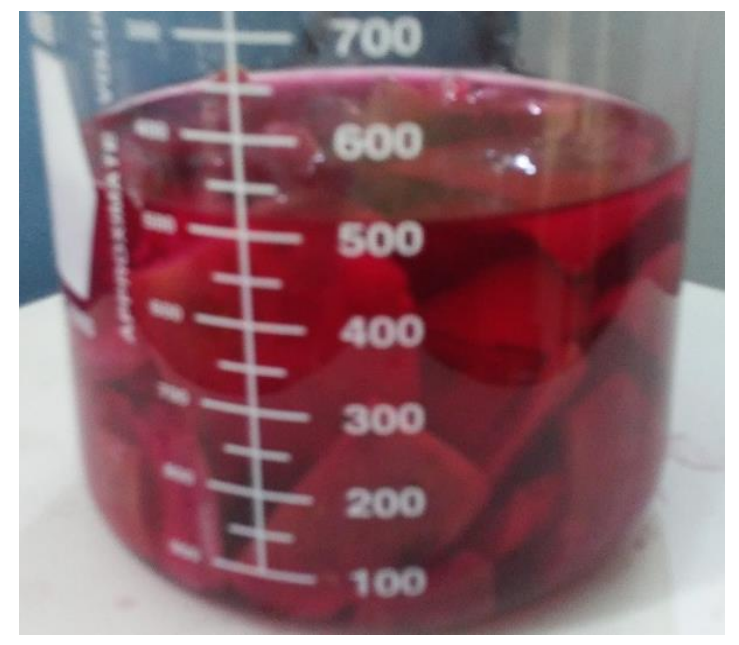

Figure 5 Raw extract of red prickly pear coloring

The content of betacyanins and betaxanthines was quantified by the methodology described above by recording the absorbance of the betacyanin extracts at $538 \mathrm{~nm}$ and that of the betaxanthines at $480 \mathrm{~nm}$. The absorbances obtained are shown in Table 3.

\begin{tabular}{|l|l|l|l|}
\hline & Betacyanins & Betaxanthines & \multicolumn{1}{c|}{ Total betalains } \\
\hline A & $7.26 \mathrm{mg} / \mathrm{g}$ & $4.74 \mathrm{mg} / \mathrm{g}$ & $12 \mathrm{mg} / \mathrm{g}$ \\
\hline B & $11.15 \mathrm{mg} / \mathrm{g}$ & $5.35 \mathrm{mg} / \mathrm{g}$ & $16.5 \mathrm{mg} / \mathrm{g}$ \\
\hline
\end{tabular}

Table 3 Total betalains content in shell (A) and pulp (B) of red prickly pears

\section{Extraction process optimization}

\section{Immersion time}

The immersion time of the pulp in the solvent was evaluated during the extraction process to establish the optimum time for maceration. In a beaker, $5 \mathrm{~g}$ of prickly pear with $100 \mathrm{ml}$ of distilled water were placed. It was subsequently placed in a magnetic stirring machine at 150 rpm.

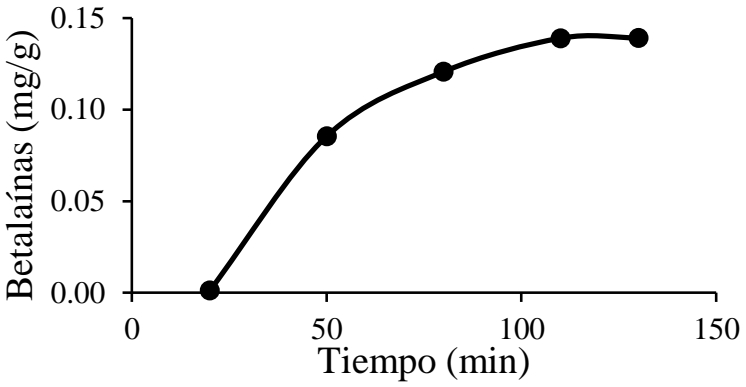

Graphic 1 Concentration of betalains as a function of the immersion time of prickly pear pulp in the solvent

It can be seen that the concentration of the dye (betalains) in the extract increases between 50 and $110 \mathrm{~min}$. Subsequently, the concentration remains almost constant, reaching a concentration of $0.140 \mathrm{mg}$ of betalains at 110 min as shown in Graphic 1.

Prakash Maran evaluated in 2012 the extraction of pigments from prickly pear pulp using water as a solvent and determined that the optimal time is 115 minutes, which coincides reasonably with the results obtained in this evaluation. On the other hand, Sánchez \& Gonzales (2006) determined an optimal immersion time of 10 minutes; however, they used as solvent a water / ethanol solution in relation to $80 / 20$.

\section{Amount of raw material processed}

For the evaluation of the amount of raw material, increasing amounts of prickly peel were macerated from 3 to $20 \mathrm{~g}$ in $100 \mathrm{ml}$ of distilled water for 120 min with magnetic stirring at $150 \mathrm{rpm}$.

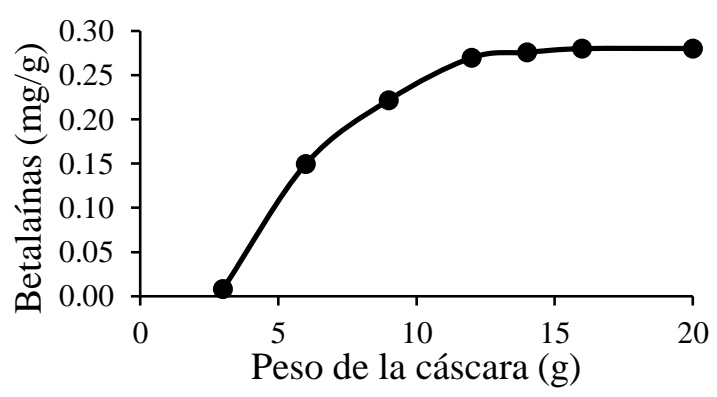

Graphic 2 Betalaine concentration in the dye extract as a function of the amount of prickly peel used in the maceration process

The concentration of the dye is increased by mashing increasing amounts from 6 to 16 grams of prickly peel. After these quantities, the concentration remains almost constant as shown in Graphic 2. The maximum concentration of betalains was $0.280 \mathrm{mg} / \mathrm{g}$ and was obtained from the maceration of $16 \mathrm{~g}$ of prickly peel in $100 \mathrm{ml}$ of water.

RAMÍREZ-GRANADOS, Juan Carlos, GÓMEZ-LUNA, Blanca Estela, MORALES-VARGAS, Adán Topiltzin and MEJÍA-TENIENTE, Laura. Betalains from prickly-pear fruit: An alternative natural coloring for food. Journal-Agrarian and Natural Resource Economics. 2019 


\section{Maceration temperature}

The maceration temperature was evaluated by placing $5 \mathrm{~g}$ of prickly peel in beakers with $100 \mathrm{ml}$ of water, which were heated to a certain temperature and kept for 40 minutes. Subsequently they were allowed to cool before measuring the concentration of betalains.

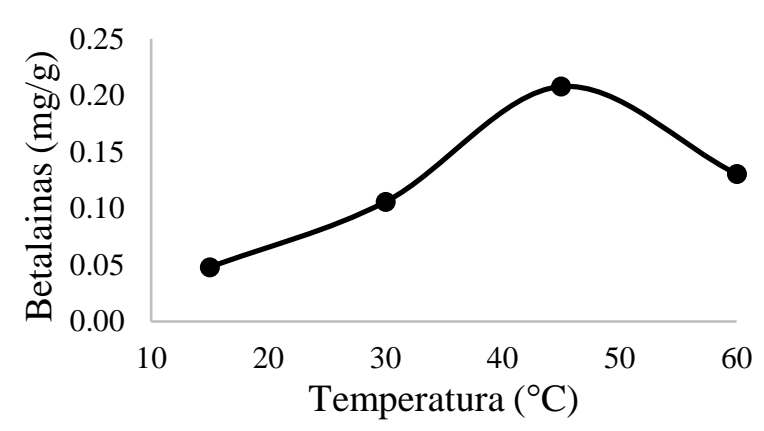

Graphic 3 Betalaine concentration as a function of solution temperature

When observing the results, it can be observed that at a temperature of $45^{\circ} \mathrm{C}$ the greatest amount of betalains with a value of $0.208 \mathrm{mg} / \mathrm{g}$ is obtained without affecting its stability (Graphic 3) as predicted by Prakash \& Maran (2012), who found that when using an extraction temperature of $40^{\circ} \mathrm{C}$ and $115 \mathrm{~min}$ of heating a maximum concentration of $35 \mathrm{mg} /$ $100 \mathrm{~g}$ of betalains was obtained.

\section{Pigment encapsulation}

One of the most used methods for obtaining natural dyes in powder form is the spray drying technique because it is the most used, economical and effective for the encapsulation of color, flavor and texture. This was used here for being the most convenient technique for its short production times and the use of low temperatures, which is crucial when the products are sensitive to heat because it promotes a high retention of taste, color and nutrients, in addition to have more economic feasibility compared to other techniques.

For the procedure, the extract of $100 \mathrm{~g}$ of plant material was obtained with the procedure described above. Subsequently, the pigment was encapsulated with corn starch (Figure 6) as described in the thesis "Obtaining an organic dye for the food industry from pitahaya," by Córdoba Torrez in 2014.

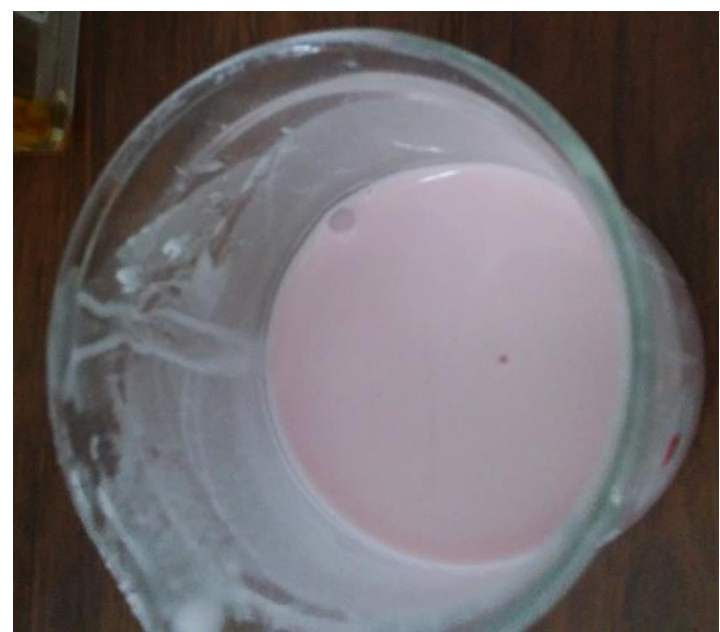

Figure 6 Encapsulation of betalains in cornstarch

This encapsulation was performed for different extract-encapsulant relationships to study differences in color and determine the best relationship for the process of encapsulation of prickly pear pigments, Table 4.

\begin{tabular}{|l|r|r|r|}
\hline Sample & \multicolumn{1}{c}{$\begin{array}{c}\text { Corn } \\
\text { starch }(\mathrm{g})\end{array}$} & $\begin{array}{c}\text { Extract } \\
\text { Volume }(\mathrm{ml})\end{array}$ & Relationship \\
\hline 1 & 25 & 30 & $1 / 1$ \\
\hline 2 & 20 & 30 & $5 / 4$ \\
\hline 3 & 15 & 30 & $5 / 3$ \\
\hline 4 & 10 & 30 & $5 / 2$ \\
\hline 5 & 5 & 30 & $5 / 1$ \\
\hline
\end{tabular}

Table 4 Extract-encapsulant ratios used to determine the best tuna dye encapsulation conditions.

Once the ratios were obtained, the beakers were stirred for 6 minutes until the mixtures were homogenized. Once the mixture was homogeneous and free of lumps, an oven was used to dry the sample at a temperature of $45^{\circ} \mathrm{C}$ for one day to obtain a dry powder (Figure 7).

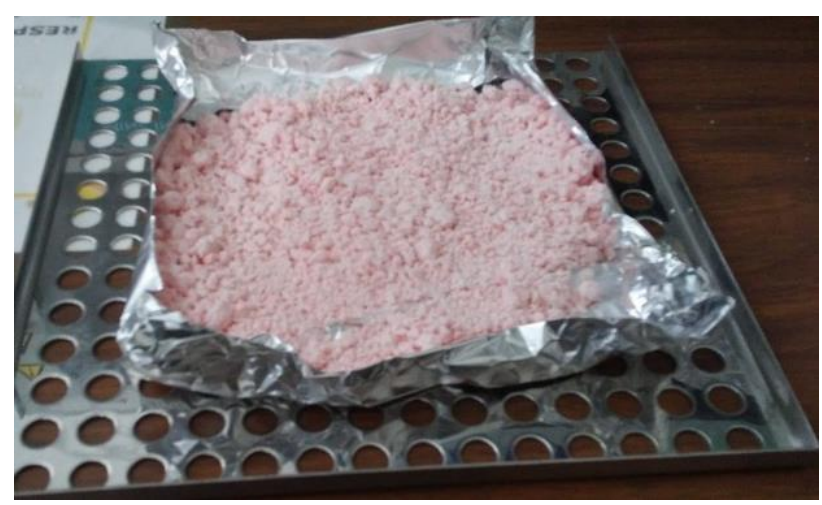

Figure 7 Drying the encapsulated dye

Once the powder was obtained, it was transferred to cellophane bags to more easily handle the encapsulated dye and weighed to compare the difference of the initial (wet) and final (dry) weight, the results are shown in Table 5. 


\begin{tabular}{|l|r|r|r|}
\hline Shows & $\begin{array}{c}\text { Initial sample } \\
\text { weight and } \\
\text { starch (g) }\end{array}$ & \multicolumn{1}{c|}{$\begin{array}{c}\text { Final } \\
\text { Weight (g) }\end{array}$} & $\begin{array}{c}\text { Weight } \\
\text { difference (g) }\end{array}$ \\
\hline $1 / 1$ & 50 & 38.72 & 11.28 \\
\hline $5 / 4$ & 45 & 31.49 & 13.51 \\
\hline $5 / 3$ & 40 & 23.53 & 16.47 \\
\hline $5 / 2$ & 35 & 15.83 & 19.17 \\
\hline $5 / 1$ & 30 & 7.49 & 22.51 \\
\hline
\end{tabular}

Table 5 Weights obtained before and after encapsulation of the dye

Table 5 shows the loss of weight during encapsulation due to the evaporation of excess moisture in the mixture. With this it can be observed that the larger the corn extract-starch ratio, the greater the weight loss. This could imply that the material can only encapsulate a certain percentage of the pigment so that the smaller ratios would not help encapsulate the entire pigment. However, the use of larger amounts of encapsulants and longer immersion times should be explored to assess whether it is possible to avoid loss of extract and see if there is a higher concentration of the encapsulated pigment.

\section{Evaluation of encapsulated betalains}

The color of the encapsulated dye samples was measured by a colorimeter. For measurements, the average color of 10 areas located in random parts of the sample was used. The results are presented below in Table 6 .

\begin{tabular}{|l|r|r|r|r|r|}
\hline & \multicolumn{5}{|c|}{ Extract / encapsulant ratio $(\mathrm{g} / \mathrm{g})$} \\
\hline $\begin{array}{l}\text { Coord. } \\
\text { chromatic }\end{array}$ & $1 / 1$ & $5 / 4$ & $5 / 3$ & $5 / 2$ & $5 / 1$ \\
\hline $\mathrm{L}$ & 89.69 & 87.57 & 88.13 & 84.68 & 86.93 \\
\hline $\mathrm{A}$ & 10.22 & 10.88 & 11.7 & 12.66 & 11.41 \\
\hline $\mathrm{B}$ & -6.31 & -5.39 & -5.72 & -4.22 & -5.17 \\
\hline
\end{tabular}

Table 6. Average color of the encapsulated extract for different extract / encapsulant ratios.

To determine the total color difference in the three chromatic coordinates the following definition was used:

$$
\Delta E=\sqrt{\Delta L^{2}+\Delta A^{2}+\Delta B^{2}}
$$

It is important to note that $\Delta \mathrm{E}$ indicates the magnitude of the total color difference. For the measurement of the color change, the sample with a $1 / 1$ ratio was considered as the reference sample to determine the difference with respect to the other relationships where the corn starch content is lower.

\begin{tabular}{|l|r|r|r|r|r|}
\hline & \multicolumn{5}{|c|}{ Extract / encapsulant ratio (g/g) } \\
\hline Color variation & $1 / 1$ & $5 / 4$ & $5 / 3$ & $5 / 2$ & $5 / 1$ \\
\hline$\Delta \mathrm{L}$ & -2.12 & -1.56 & -5.01 & -2.76 & -2.12 \\
\hline$\Delta \mathrm{A}$ & 0.66 & 1.48 & 2.44 & 1.19 & 0.66 \\
\hline$\Delta \mathrm{B}$ & 0.92 & 0.59 & 2.19 & 1.14 & 0.92 \\
\hline$\Delta \mathrm{E}$ & $\mathbf{2 . 4 0 3}$ & $\mathbf{2 . 2 3 0}$ & $\mathbf{5 . 9 8 7}$ & $\mathbf{3 . 2 1 5}$ & $\mathbf{2 . 4 0 3}$ \\
\hline
\end{tabular}

Table 7 Color difference for various extract / encapsulant ratios

Table 7 shows that the different encapsulations have a color difference. The chromatic coordinate $\mathrm{L}$ indicates the brightness of the sample, the value A refers to the region of the color space where the shades range from green (negative) to red (positive), value B refers to the region of the color space where the shades range from yellow (negative) to blue (positive).

When observing the results of the different samples, it was found that the relationship with the most difference in luminosity, red-green and yellow-blue hue, compared to the sample with $1 / 1$ ratio, is the sample with a $5 / 3$ ratio which has a total color difference of 5,987. This is interesting since with this differences in color are observed by modifications in the encapsulation. This may suggest that when using the $5 / 3$ ratio the compound of interest, in this case betalains, is more concentrated and therefore the total color difference is greater than for samples with other relationships.

The time that the extract and the encapsulating agent were in contact was 6 minutes, but from what was observed in the colorimetric analysis it would be interesting to use longer immersion times to know if the analyte can be concentrated more effectively, in addition to quantifying the encapsulated betalains.

\section{Acknowledgments}

This work was carried out with the support of the Rectory of the Celaya-Salvatierra Campus of the University of Guanajuato. The support of Mario Alberto Lozano Servín for his valuable collaboration is also appreciated. 


\section{Conclusions}

Prickly pears are an important source of natural dyes. It was found that the weight of the prickly pear peel Cardona represents $47.61 \%$ of the total weight of this fruit, which makes it a viable material for the extraction of natural dyes since added value would be given to a waste material. Through the quantitative analysis of the extract, a maximum concentration of $12 \mathrm{mg} / \mathrm{g}$ of betalains was obtained in the peel of the prickly pear Cardona; while a maximum concentration of $16.5 \mathrm{mg} / \mathrm{g}$ was obtained in the pulp, this being an indication that both the pulp and the skin of the red prickly pears have a high betalaine content.

Considering the cost of the raw material, the most suitable plant material for the extraction of reddish dyes is the shell because it has no commercial value, unlike the pulp that is used as food. On the other hand, when evaluating different variables to optimize the extraction process, it was found that the optimal immersion time for maceration is 110 minutes, since it allows obtaining a higher concentration of betalains. As for the amount of raw material, it was found that, the more matter, the higher the concentration of betalains. In this aspect, a saturated solution with $0.280 \mathrm{mg} / \mathrm{g}$ of betalains was obtained by macerating $16 \mathrm{~g}$ of raw material in $100 \mathrm{ml}$ of water.

With respect to the effect of temperature on the extraction process, betalains are known to degrade when subjected to temperatures greater than $60^{\circ} \mathrm{C}$ for periods greater than one hour. By subjecting the aqueous extract to different temperatures it was found that the highest concentration of betalains was obtained at $45^{\circ}$ $\mathrm{C}$; at higher temperatures there is a decrease in betalains in the extract.

The exposure time of the extract at these temperatures is also an important factor since, the longer the exposure time, the greater the degradation of the pigment. In addition, when performing the encapsulation of the dye in the corn starch, the effect of the different extract / encapsulant ratios on the color of the sample was studied. It was observed that at a higher extract / encapsulant ratio, the loss of extract is greater during drying. When performing a colorimetric analysis, it was found that the $5 / 3$ ratio has the largest total color difference with a value of 5,987 , which indicates that the sample with this ratio would have a higher betalaine content.

\section{References}

Badui Dergal, S., \& Cejudo Gómez, H. R. T. Química de los alimentos. Pearson Education, 2006.

Castellanos-Santiago, E., \& Yahia, E. M. (2008). Identification and quantification of betalains from the fruits of 10 Mexican prickly pear cultivars by high-performance liquid chromatography and electrospray ionization mass spectrometry. Journal of Agricultural and Food Chemistry, 56(14), 5758-5764.

Carrera, R., Flores, L., Valverde, P., \& Llangari, K. (2019). Obtención del colorante natural de tuna (Opuntia ficus-indica). Ciencia Digital, 3(3.2), 232-240.

CODEX STAN 192-1995 Norma General para los Aditivos Alimentarios.

Contreras Ovalle, N. I. Estudio de los factores que afectan la producción de pigmentos betalaínicos en raíces transformadas de cactáceas. Tesis doctoral. Universidad Autónoma de Aguascalientes, 2019.

Dutta, P., S. et al. (2009). Review: Perspectives for chitosan based antimicrobial films in food applications. J. Food Chem. 114(4): 1173-1182. Fuchs, M., C. et al. (2006). Encapsulation of oil in powder using spray drying and fluidized bed agglomeration. Journal of Food Engineering 75(1): 27-35.

Gibbs, B. et al. (1999). Encapsulation in the food industry: a review. International Journal of Food Sciences and Nutrition 50, 213-224.

González, A. M., \& Vicente, I. El color en la industria de los alimentos. Editorial Universitaria, La Habana, Cuba, 2007.

González, A. E. Aplicación de pulsos eléctricos de alto voltaje en la extracción de pigmentos y compuestos antioxidantes de tunas rojas (Opuntia spp.). Tesis. UAEH, 2014.

Gutiérrez, J. B. (2012). Calidad de vida, alimentos $y$ salud humana: fundamentos científicos. Ediciones Díaz de Santos.

Huaman-Gongora, L. A. (2014). Evaluación del tipo de solvente en el rendimiento durante la extracción de colorante natural de la cascara de tuna morada (opuntia ficus).

RAMÍREZ-GRANADOS, Juan Carlos, GÓMEZ-LUNA, Blanca Estela, MORALES-VARGAS, Adán Topiltzin and MEJÍA-TENIENTE, Laura. Betalains from prickly-pear fruit: An alternative natural coloring for food. Journal-Agrarian and Natural Resource Economics. 2019 
Montes, E., C. De Paula \& Ortega F. (2007). Determinación de las condiciones óptimas de encapsulamiento por co-cristalización de jugo de maracuya (Passiflora edulis). Revista Temas Agrarios 12: 5-12.

Pedroza, R. (2002). Alimentos Microencapsulados: Particularidades de los Procesos para la Microencapsulación de Alimentos para Larvas de Especies Acuícolas. Memorias del VI Simposium Internacional de Nutrición Acuícola, Mx.

Piattelli, M. The betalains: structure, biosynthesis, and chemical taxonomy. The biochemistry of plants, 557-575, 1981.

Prakash Maran (2012). Response surface modeling and optimization of process parameters for aqueous extraction of pigments from prickly pear (Opuntia ficus-indica) fruit.

Sánchez (2006). Caracterización de los principales pigmentos del Opuntia joconoste.

Sánchez González, N. Extracción y caracterización de los principales pigmentos del Opuntia joconoste cv (xoconostle) Tesis Doctoral, 2013.

Santinho, A. J. et al. (2002). Physicochemical characterization and enzymatic degradation of casein microcapsules prepared by aqueous coacervation. J Microencapsulation 19, 549559.

Wang, J. P. et al. (2004). Preparation of microcapsules containing two-phase core materials. Langmuir 20, 10845-10850.

Yañez, J. et al. (2002). Aplicaciones biotecnológicas de la microencapsulación. Revista Avance y Perspectiva 21: 313-319.

Zong, M. et al. (2009). Microencapsulation of tamoxifen: Application to cotton fabric. Colloids and Surfaces. Biointerfaces 69(1): 85-90. 